Article

\title{
Evolution of Microstructure and Mechanical Properties in a Single-Stage Aged 7075 Aluminum Alloy Pulse Variable Polarity Plasma Arc Welded Joint
}

\author{
Guowei Li, Yahong Liang *, Furong Chen, Yongquan Han and Li Sun
}

School of Materials Science and Engineering, Inner Mongolia University of Technology, Hohhot 010051, China; liguowei-2008@imut.edu.cn (G.L.); cfr7075@imut.edu.cn (F.C.); hyq@imut.edu.cn (Y.H.); nmsunnyli@163.com (L.S.)

* Correspondence: liangyahong@imut.edu.cn; Tel./Fax: +86-471-6575752

Received: 11 March 2019; Accepted: 8 April 2019; Published: 10 April 2019

\begin{abstract}
A 7075 aluminum alloy was successfully welded by pulsed variable polarity plasma arc welding (PVPPAW) and the single-stage aging behavior of the 7075 aluminum alloy PVPPAW joint was systematically investigated. The results demonstrated that the tensile strength of the welded joints initially increased and then decreased with the increase of the single-stage aging temperature and time. After single-stage aging at $490^{\circ} \mathrm{C}$ for $80 \mathrm{~min}$ and at $130^{\circ} \mathrm{C}$ for $24 \mathrm{~h}$, the tensile strength of the welded joint was $551 \mathrm{MPa}$, which was increased by $38.5 \%$ compared to the as-welded joint. Moreover, the conductivity was $25 \%$ international annealed copper standard (IACS) at room temperature, and the resistance to stress corrosion was improved. The main strengthening phases of the weld center were $\eta^{\prime}$ and $\eta$ phase. The average precipitate size slightly increased with the increase of the single-stage aging temperature, but no obvious change was observed with the increase of the single-stage aging time. The area fraction was initially increased and then decreased with the increase of the single-stage aging temperature and time.
\end{abstract}

Keywords: 7075 aluminum alloy; PVPPAW; single-stage aging; microstructure; properties

\section{Introduction}

Due to their excellent mechanical properties, $7 \times \times \times$ series high-strength aluminum alloys are widely used in aerospace, national defense, navigation, automobile, and other fields [1-6]. A proper welding method is often needed in practical applications, and achieving high-quality welding has been a hot and challenging research topic $[7,8]$. Compared to other traditional fusion welding techniques, PVPPAW technology has significant advantages in welding aluminum alloys [9-11], such as the small deformation, energy concentration, absence of a need for groove preparation, narrow weld bead, one-sided welding, and both sides formation. However, there are some limitations, including the strength loss and poor corrosion resistance of welded joints [12,13], which affect, to a certain extent, the further development and application of the Al- $\mathrm{Zn}-\mathrm{Mg}-\mathrm{Cu}$ aluminum alloy.

Methods for improving the softening and corrosion resistance of welded joints have been the research focus of many researchers. In general, heat treatment is a key process to improve the mechanical properties of $7 \times \times \times$ series high-strength aluminum alloys [14-19]. Single-stage aging treatment is one of the main methods used to enhance the mechanical properties of aluminum alloys [20]. Several researchers [21-23] have found that single-stage aging treatment can not only enhance the strength of $7 \times \times \times$ series aluminum alloys, but also improve the performance of $7 \times \times \times$ series aluminum alloy welded joints. Kumar et al. [24] found that the strength and hardness of an AA7075 aluminum alloy friction stir welded joint were significantly improved after T6 heat treatment, but the welds 
demonstrated poor corrosion resistance. Moreover, the resistance to pitting corrosion was improved by retrogression and re-aging treatment with minimum loss of weld strength. Wang et al. [25] investigated the effects of heat treatment on high-strength aluminum alloy friction stir welded joints. The tensile strength reached $415 \mathrm{MPa}$, which was nearly $89.5 \%$ of that of the base metal, the microhardness of the joints was significantly increased, and a more uniform hardness distribution was achieved after heat treatment. Chen et al. [26] investigated the one-step aging behavior of a 7A52 aluminum alloy laser welded joint. The age hardening speed of the joint was significantly accelerated, and the time to peak hardness was significantly reduced when the aging temperature increased from $120{ }^{\circ} \mathrm{C}$ to $160{ }^{\circ} \mathrm{C}$. Aging at $140^{\circ} \mathrm{C}$ for $16 \mathrm{~h}$ was considered as a reasonable one-step aging process. Yan et al. [27] investigated the influence of heat treatment on the microstructure and mechanical properties of a spray formed $7 \times \times \times$ series aluminum alloy tungsten inert gas (TIG) welded joint. Their results demonstrated that the microstructure of the weld was homogenous without overburning, the grain size increased slightly after solution treatment, and the strength of the welded joint was improved by about $70 \%$ after heat treatment. Therefore, single-stage aging treatment should be an effective way to improve the mechanical properties of $7 \times \times \times$ series aluminum alloy welded joints.

In this study, the optimized PVPPAW process was used to weld 7075 aluminum alloy sheets. After solution treatment, the samples were quenched by water and then treated by single-stage aging. The effect of solution treatment on the microstructure and mechanical properties has been investigated in our previous work [28], where the solution treatment process was optimized, and the variation of the size and number of $\mathrm{T}$ phases were analyzed. In the present study, the changes in the microstructure and mechanical properties of welds with different applied single-stage aging processes were investigated, and the effects of single-stage aging treatment on the structure and mechanical properties of the 7075 aluminum alloy PVPPAW joint were systematically analyzed.

\section{Materials and Methods}

The material used in the present study was sheets of 7075-T651 aluminum alloy produced by Southwest Aluminum Company Co., Ltd. (Chongqing, China), with a chemical composition of (wt.\%) 5.1-6.1 Zn, 2.1-2.9 Mg, 1.2-2.0 Cu, 0.3 Mn, 0.2 Ti, 0.18-0.28 Cr, 0.5 Fe, 0.4 Si, and balance Al. ER5183 (Al-Mg alloy) with a diameter of $1.2 \mathrm{~mm}$ and chemical composition of (wt.\%) $0.25 \mathrm{Zn}, 4.3-5.2 \mathrm{Mg}$, $0.1 \mathrm{Cu}, 0.5-1.0 \mathrm{Mn}, 0.15 \mathrm{Ti}, 0.05-0.25 \mathrm{Cr}, 0.4 \mathrm{Fe}, 0.4 \mathrm{Si}$, and balance Al was used as the filler wire. The mechanical properties of the 7075 aluminum alloy and ER5183 welding wire are shown in Table 1.

Table 1. Mechanical properties of 7075 aluminum alloy and ER5183 welding wire.

\begin{tabular}{ccccc}
\hline Alloy & Tensile Strength (MPa) & Yield Strength (MPa) & Elongation (\%) & Hardness (HV) \\
\hline 7075 & 589 & 535 & 12 & 150 \\
5183 & 310 & 180 & 12 & 68 \\
\hline
\end{tabular}

A VPPA-300 welding power supply and a PMW-300 plasma arc welding torch were used in the experiments, the welding equipment is shown in Figure 1, while 99.9\% argon gas was used as both plasma and shielding gas. The joint weld type was butt welding, and the welding parameters [28] of PVPPA are shown in Table 2. 


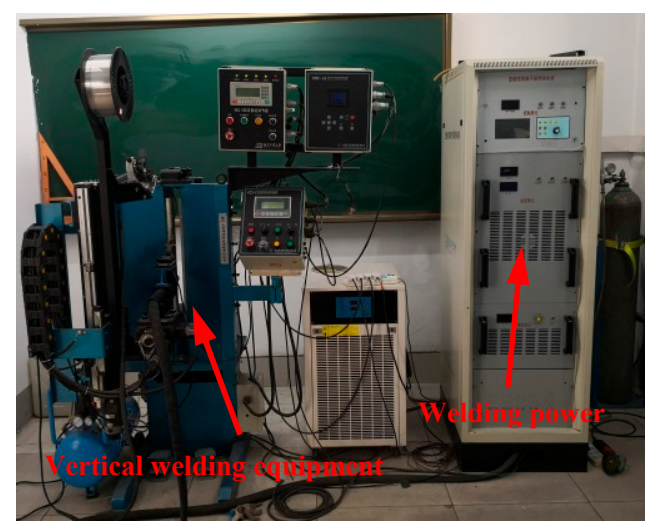

Figure 1. Welding equipment.

Table 2. Welding parameters of PVPPA.

\begin{tabular}{cccccc}
\hline $\begin{array}{c}\text { Welding } \\
\text { Parameters }\end{array}$ & $\begin{array}{c}\text { Positive } \\
\text { Polarity } \\
\text { Current (A) }\end{array}$ & $\begin{array}{c}\text { Reversed } \\
\text { Polarity } \\
\text { Current (A) }\end{array}$ & $\begin{array}{c}\text { Welding } \\
\text { Speed } \\
\left(\mathbf{m m} \cdot \mathbf{m i n}^{-1}\right)\end{array}$ & $\begin{array}{c}\text { Wire Feeding } \\
\text { Speed } \\
\left(\mathbf{m m} \cdot \mathbf{m i n}^{-1}\right)\end{array}$ & $\begin{array}{c}\text { Plasma Gas } \\
\text { Flow Rate } \\
\left(\mathbf{d m}^{\mathbf{3}} \cdot \mathbf{m i n}^{-\mathbf{1}}\right)\end{array}$ \\
\hline Value & $240-260$ & $280-300$ & 150 & 220 & 2.0 \\
$\begin{array}{c}\text { Welding } \\
\text { Parameters }\end{array}$ & $\begin{array}{c}\text { Protection Gas } \\
\text { Flow Rate } \\
\left(\mathbf{d m}^{\mathbf{3}} \cdot \mathbf{m i n}^{-1}\right)\end{array}$ & $\begin{array}{c}\text { Tungsten } \\
\text { Electrode } \\
\text { Neck-in }(\mathbf{m m})\end{array}$ & Time Ratio & $\begin{array}{c}\text { High } \\
\text { Frequency } \\
(\mathbf{H z})\end{array}$ & $\begin{array}{c}\text { Low } \\
\text { Frequency } \\
(\mathbf{H z})\end{array}$ \\
\hline Value & 15 & 3 & $21: 4$ & 50 & 1 \\
\hline
\end{tabular}

The welding sample dimensions were $100 \times 80 \times 10 \mathrm{~mm}^{3}$, and the edge of the specimens were welded along the longitudinal direction. The mechanical properties were tested at room temperature using a SHT-4605 universal testing machine (Shanghai SANS Measuring instrument manufacturing Co., Ltd., Shanghai, China), under a loading speed of $1 \mathrm{~mm} / \mathrm{min}$. The tensile tests were performed according to the Chinese GB/T 2651-2008 standard. A schematic illustration of the welded joint is shown in Figure 2. The mechanical properties of the samples were measured perpendicular to the axial direction of the weld, and the weld reinforcement of the front and back surface of the specimens was removed to reduce the stress concentration. The initial gauge length of each sample was $60 \times 12 \times 10 \mathrm{~mm}^{3}$. To ensure the reliability of the measured data, at least three specimens were tested for each condition. The macroscopic structure was observed using optical microscopy (Carl Zeiss AG, Oberkochen, Germany) after being treated by mechanical and electrical polishing, and then etching by the Keller solution of $\mathrm{HNO}_{3}: \mathrm{HCl}: \mathrm{HF}: \mathrm{H}_{2} \mathrm{O}=2.5: 1.5: 1: 95$ (vol.\%). The micro-area composition was observed by a Tecnai G2 F20 transmission electron microscope (TEM, FEI Company, Hillsboro, OR, USA). TEM specimens with a thickness of $1 \mathrm{~mm}$ were cut by wire cutting and mechanically polished to thick disks of approximately $60 \mu \mathrm{m}$. The final thinning was prepared by twin-jet electro-polishing in a mixture solution of $75 \%$ methanol and $25 \%$ nitric acid (vol.\%) at approximately $-25^{\circ} \mathrm{C}$ and $15 \mathrm{~V}$. The resistivity was measured at room temperature by a SIGMASCOPE SMP 10 conductometer (Linseis Messgeräte $\mathrm{GmbH}$, Vielitzer, Germany), and electrical conductivity is the reciprocal of resistivity. The sample thickness was $3 \mathrm{~mm}$ and the diameter was $12 \mathrm{~mm}$. The Vickers micro-hardness was measured using an HXD-1000TM microhardness tester (Shanghai Taiming Optical Instrument Co., Ltd., Shanghai, China) with an applied load of $200 \mathrm{~g}$ for $15 \mathrm{~s}$. 

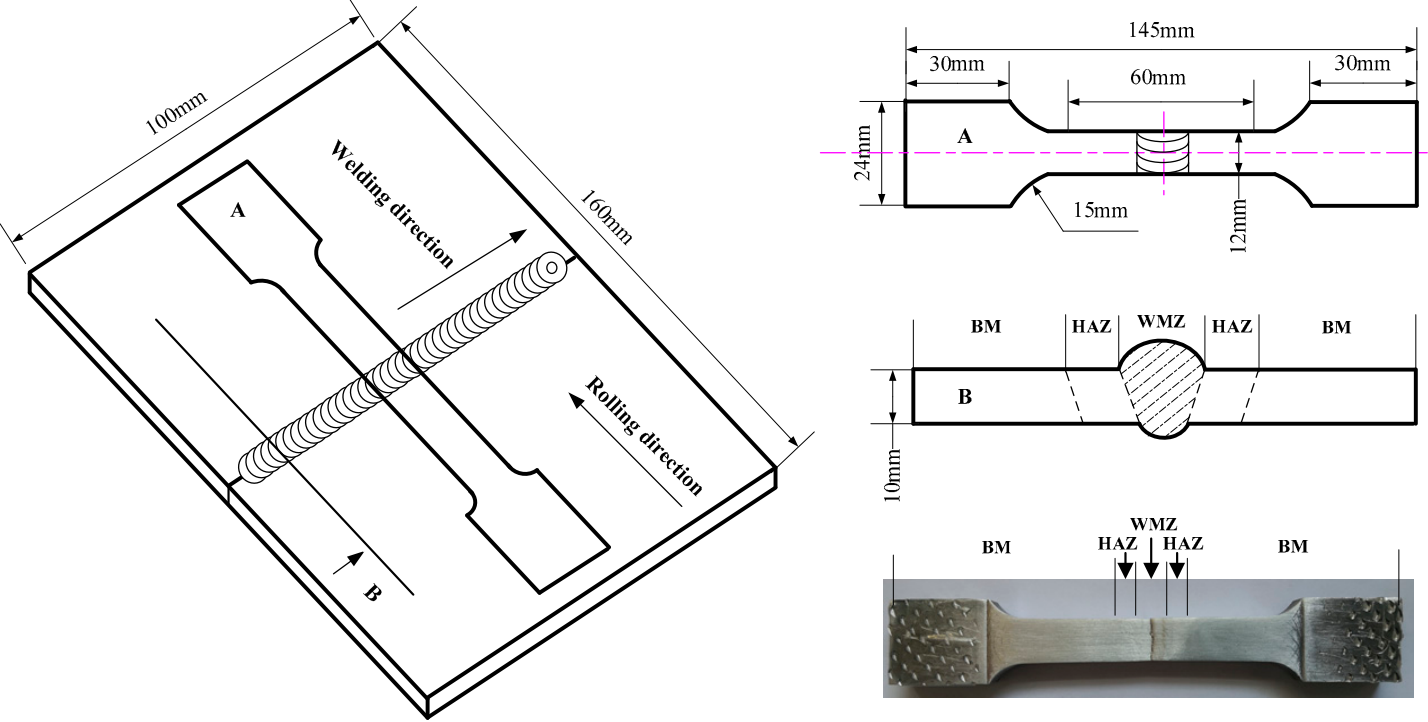

Figure 2. Schematic illustration of the welded joint and an indication of various zones across the weld.

BM: base metal, HAZ: heat affected zone, WMZ: weld metal zone.

In order to study the evolution of microstructure and mechanical properties in the single-stage aged 7075 aluminum alloy PVPPAW joints, the welded joint was solution-treated at $490^{\circ} \mathrm{C}$ for $80 \mathrm{~min}$, and was subsequently quenched in water at $25^{\circ} \mathrm{C}$. Then, it was aged at $100{ }^{\circ} \mathrm{C}, 110^{\circ} \mathrm{C}, 120^{\circ} \mathrm{C}, 130^{\circ} \mathrm{C}$, and $140^{\circ} \mathrm{C}$ for $24 \mathrm{~h}$. After the optimum temperature was determined, different aging times of $12 \mathrm{~h}$, $16 \mathrm{~h}, 20 \mathrm{~h}, 24 \mathrm{~h}$, and $28 \mathrm{~h}$ were investigated.

\section{Results}

\subsection{Microstructure of the 7075 Aluminum PVPPAW Joint}

The optical microstructures of the 7075 aluminum alloy PVPPAW joint can be seen in Figure 3. As it can be observed from Figure 2, the welded joint consists of a base metal (BM) zone, a heat affected zone (HAZ), and a weld metal zone (WMZ). As shown in Figure 3, the BM exhibited a typical rolling microstructure, the HAZ showed an equiaxed grain shape, and the WMZ consisted of coarse dendrites. The morphology of the microstructure is closely related to the heating state and physical characteristics of the aluminum alloy during welding. The PVPPAW method has a high energy density and fast welding speed. The WMZ is the center of the heat input, leading to a small temperature gradient. The fact that the duration at high temperature was longer and the grain growth time was abundant resulted in the formation of a dendritic structure in the WMZ. The temperature of HAZ was increased by the heat dissipation, which reached the recrystallization temperature of the $B M$, and thus partially equiaxed grains were formed by recrystallization of the rolled structure. The microstructure of the BM was unchanged.
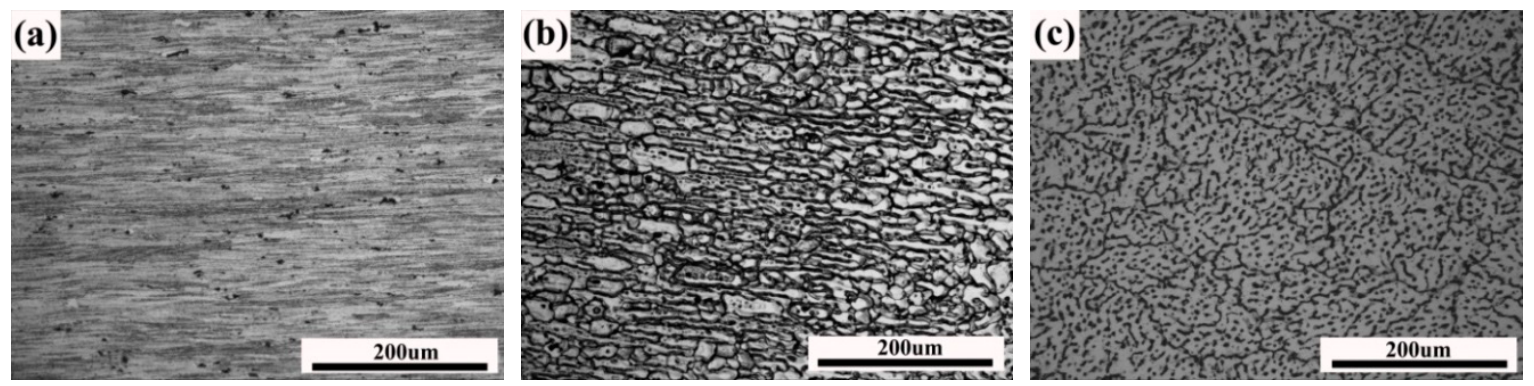

Figure 3. Optical microstructures of the welded joint: (a) BM; (b) HAZ; and (c) WMZ. 


\subsection{Effect of Single-Stage Aging Temperature on the Mechanical Properties}

The influence of the single-stage aging temperature on the mechanical properties of welded joints was investigated. Figure 4 shows the change trend of tensile strength and electrical conductivity of welded joints at different single-stage aging temperatures for $24 \mathrm{~h}$. The fracture of the welded joints occurred in the WMZ. The tensile strength of the as-welded joint was $398 \mathrm{MPa}$, which was about $67.5 \%$ of that of the base metal. After solution treatment and single-stage aging, the tensile strength increased to a peak value, and then decreased with the increase of the single-stage aging temperature. The tensile strength of the welded joint at $100{ }^{\circ} \mathrm{C}$ was $497 \mathrm{MPa}$, which was nearly $84.3 \%$ of that of the BM. As the single-stage aging temperature increased, the tensile strength of the welded joint was gradually improved. The highest tensile strength of $551 \mathrm{MPa}$ was achieved at $130{ }^{\circ} \mathrm{C}$, which was nearly $93.5 \%$ of that of the BM, and it was increased by $38.5 \%$ compared to the as-welded joint.

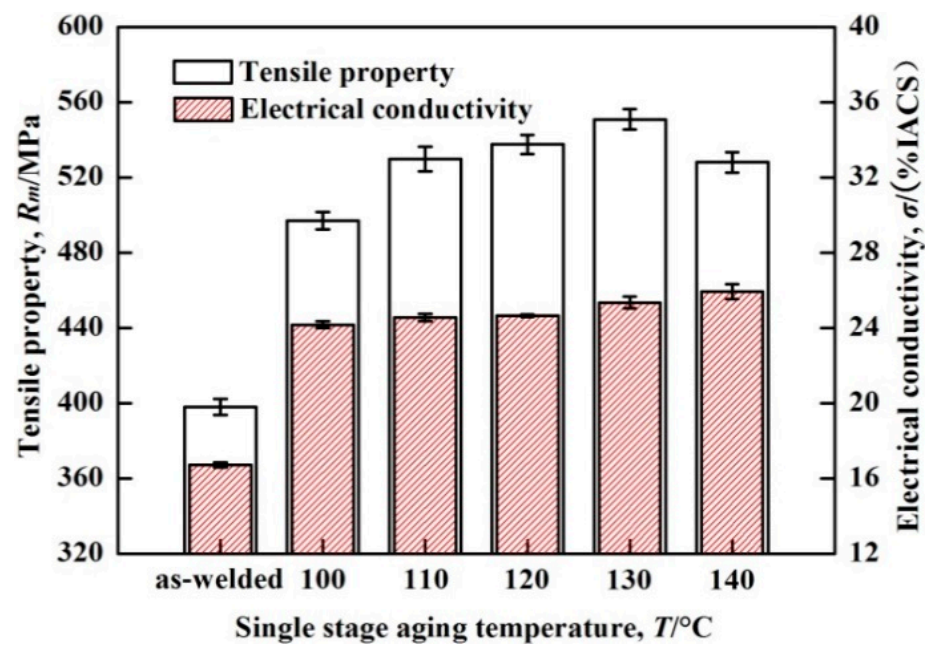

Figure 4. Tensile properties and electrical conductivities of welded joints aged at different temperatures for $24 \mathrm{~h}$.

However, the tensile strength of the welded joint at $140{ }^{\circ} \mathrm{C}$ decreased slightly compared to that at $130{ }^{\circ} \mathrm{C}$. According to Figure 4 , the tensile strength of the welded joint was evidently improved by single-stage aging. Moreover, the electrical conductivity increased slowly when the temperature was between $100{ }^{\circ} \mathrm{C}$ and $120^{\circ} \mathrm{C}$, but increased rapidly when the temperature was further increased. The electrical conductivity of the as-welded joint was 17\% IACS at room temperature, and it increased from $22 \%$ IACS at $110{ }^{\circ} \mathrm{C}$ to $26 \%$ IACS at $140{ }^{\circ} \mathrm{C}$. It can be seen that the stress corrosion resistance of the welded joints increased with the increase of the single-stage aging temperature [29]. Based on the tensile strength results, the optimum aging temperature was $130{ }^{\circ} \mathrm{C}$. The same trend was also observed in the results of the welded joints microhardness.

Figure 5 shows the microhardness distribution of the welded joints at different temperatures for $24 \mathrm{~h}$ with a load of $200 \mathrm{~g}$ for $15 \mathrm{~s}$. As it can be observed, the microhardness initially increased, and then, as the temperatures increased, it decreased. The microhardness of the weld center increased from $127 \mathrm{HV}$ of the as-welded joint to $145 \mathrm{HV}$ of the joint heat-treated at $130{ }^{\circ} \mathrm{C}$. After single-stage aging, the microhardness of the weld center was still the smallest, much lower than that of the BM, and the microhardness of the HAZ was significantly enhanced. The highest microhardness values of the weld center and the HAZ were obtained when the temperature was $130^{\circ} \mathrm{C}$. 


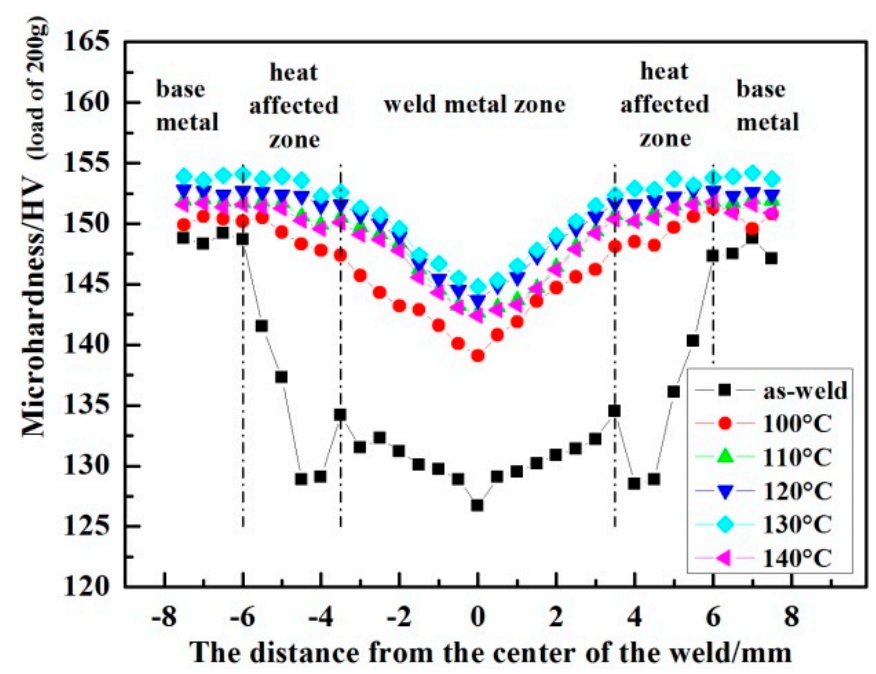

Figure 5. Microhardness distributions of welded joints aged at different temperatures for $24 \mathrm{~h}$.

\subsection{Effect of Single-Stage Aging Time on the Mechanical Properties}

The variation of tensile strength and electrical conductivity of welded joints at $130{ }^{\circ} \mathrm{C}$ for different single-stage aging times can be seen in Figure 6. With the increase of the single-stage aging time, the tensile strength of the welded joint initially increased and then decreased. The tensile strength of the welded joint was $482 \mathrm{MPa}$ after being aged for $12 \mathrm{~h}$, while the maximum tensile strength was $551 \mathrm{MPa}$ after $24 \mathrm{~h}$. The electrical conductivity of the welded joints increased with the increase of aging time. After $24 \mathrm{~h}$, the electrical conductivity reached $24 \%$ IACS, and then, after $28 \mathrm{~h}$, increased to $26 \%$ IACS. Based on the tensile strength results, the optimum single-stage aging time was $24 \mathrm{~h}$.

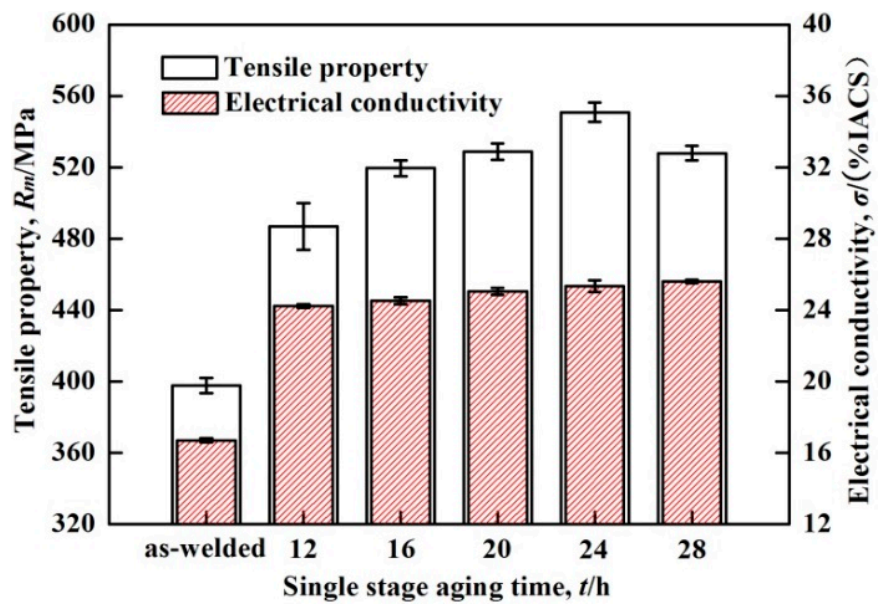

Figure 6. Tensile properties and electrical conductivities of welded joints aged at $130{ }^{\circ} \mathrm{C}$ for different times.

Figure 7 shows the microhardness distribution of the welded joints at $130{ }^{\circ} \mathrm{C}$ for different times with a load of $200 \mathrm{~g}$ for $15 \mathrm{~s}$. As it can be observed, the microhardness of welded joints initially increased, and then, as the aging time increased, it decreased. The microhardness of the weld center was $138 \mathrm{HV}$ after $12 \mathrm{~h}$ and increased to $145 \mathrm{HV}$ after $24 \mathrm{~h}$ of aging. As the aging time increased, the microhardness decreased to $143 \mathrm{HV}$. After single-stage aging treatment, the microhardness of the weld center was higher than that of the as-welded joint. The microhardness of the HAZ was evidently improved, but it was still lower than that of the BM. The highest microhardness values of the weld center and HAZ were obtained after $24 \mathrm{~h}$ of aging. 


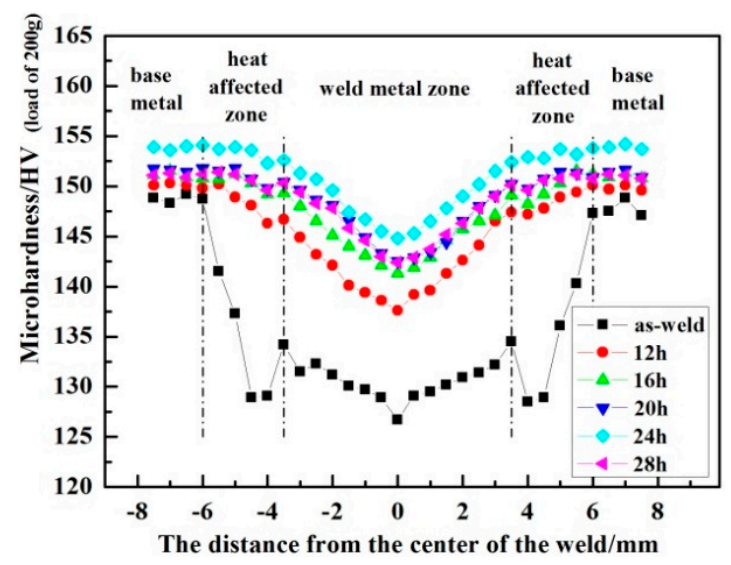

Figure 7. Microhardness distributions of welded joints aged at $130{ }^{\circ} \mathrm{C}$ for different times.

\subsection{Effect of Single-Stage Aging Temperature on the Microstructure}

In Figure 8, TEM images of the welded joints at different single-stage aging temperatures for $24 \mathrm{~h}$ are demonstrated. As it can be seen in Figure 8, the precipitation phase was formed in the grain interior at different temperatures. In addition, typical TEM images with corresponding selected area electron diffraction (SAED) patterns of precipitates are displayed in Figure 9. Based on the analyses, a kind of weak spot appeared at the $1 / 3\{02 \overline{2}\}$ position in the diffraction pattern taken along the [011] zone axis and at the $2 / 3\{\overline{2} 20\}$ position in the diffraction pattern taken along the [001] zone axis. These spots were identified as $\eta^{\prime}$ and $\eta$ phases, the chemical composition of $\mathrm{MgZn}_{2}$ [30-32]. There were no extra spots other than those in the $\alpha$-Al matrix, suggesting the presence of fine precipitates in the aged specimen, which can be seen in Figure 8a, where the Guinier-Preston (GP) zone precipitates have the same crystal structure as the matrix [33]. As it can be observed in Figure 8a, the particle size of the $\eta^{\prime}$ phase was very small and its distribution was uniform. Furthermore, in Figure $8 b$, the size of the $\eta^{\prime}$ phase increased slightly at $130{ }^{\circ} \mathrm{C}$ for $24 \mathrm{~h}$, while its density increased significantly.
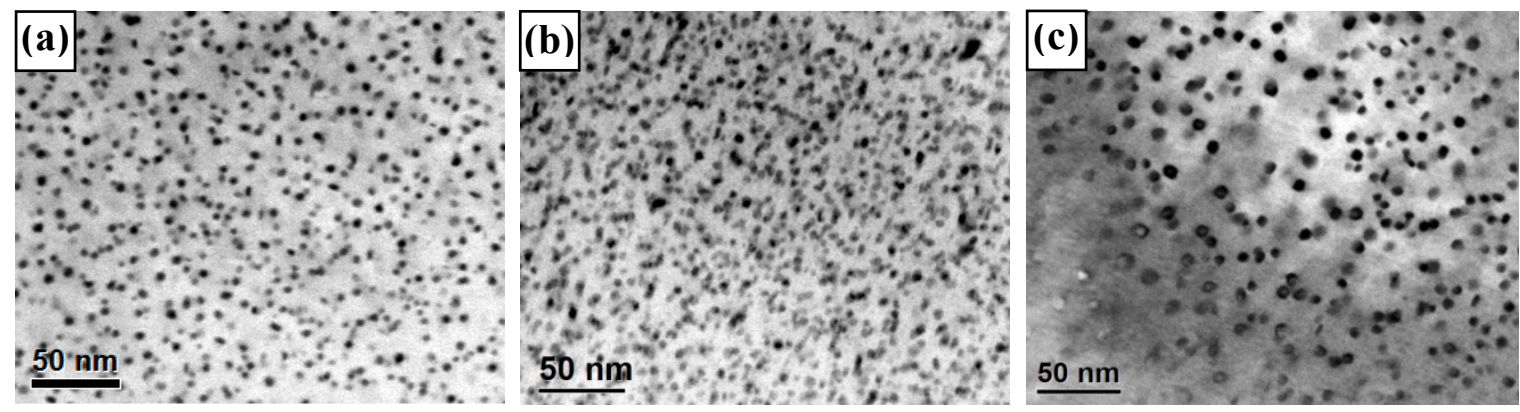

Figure 8. TEM (transmission electron microscope) images of the weld center aged at different temperatures for $24 \mathrm{~h}$ (a) $120^{\circ} \mathrm{C}$; (b) $130{ }^{\circ} \mathrm{C}$; (c) $140{ }^{\circ} \mathrm{C}$.
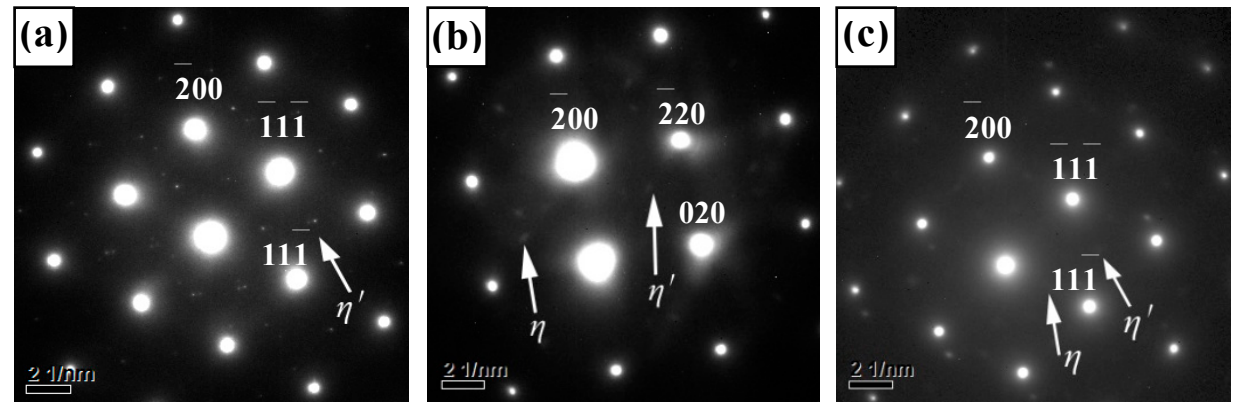

Figure 9. SAED (selected area electron diffraction) patterns of the weld center aged at different temperatures for $24 \mathrm{~h} \mathrm{(a)} 120^{\circ} \mathrm{C}<011>$; (b) $130{ }^{\circ} \mathrm{C}<001>$; (c) $140{ }^{\circ} \mathrm{C}<011>$. 
After aging at $140{ }^{\circ} \mathrm{C}$ for $24 \mathrm{~h}$, the density of the precipitated phase was smaller than that at $130{ }^{\circ} \mathrm{C}$. As it can be seen in Figure $8 \mathrm{c}$, the $\eta^{\prime}$ and $\eta$ phase in the grains' interior were coarsened remarkably. Moreover, in the analysis of the diffraction pattern taken along the [011] zone axis by the schematic diffraction pattern of Refs. [30,34], the $\eta^{\prime}$ phase was found to transform to $\eta$ phase after aging at $140{ }^{\circ} \mathrm{C}$. Due to the difficulty in quantitatively measuring the accurate precipitate size and area fraction from Figure 8, the average precipitate size and area fraction under three different aging temperatures were semi-quantitatively measured [14] and the results are presented in Figure 10. The qualitative comparison of these results indicated that the average precipitate size and area fraction of the precipitates at $130{ }^{\circ} \mathrm{C}$ appeared to be smaller and higher than those at the other two temperatures, respectively. The shape of the precipitates was spherical and plate-like, while the average precipitate size was approximated from the average measurements on the long and short axes of the precipitates. As it can be seen in Figure 10, at $120^{\circ} \mathrm{C}$, the fine precipitates were in the size range of $4-6 \mathrm{~nm}$, with an average precipitate size of $5 \mathrm{~nm}$ and an area fraction of $18.3 \%$. With the increase of temperature to $130{ }^{\circ} \mathrm{C}$, the average precipitate size remained in the range of $4-6 \mathrm{~nm}$, with an average precipitate size of $5 \mathrm{~nm}$, while the area fraction increased to $34.6 \%$. Then, at $140{ }^{\circ} \mathrm{C}$, the average precipitate size increased to a size range of $5-8 \mathrm{~nm}$ and the area fraction decreased to $19.6 \%$.

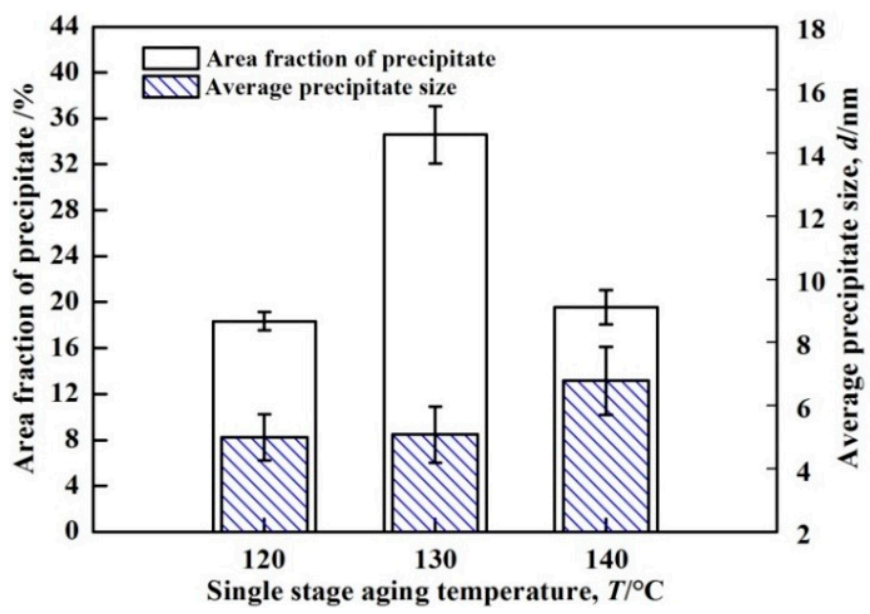

Figure 10. Area fraction of precipitates and average precipitate sizes aged at different temperatures for $24 \mathrm{~h}$.

\subsection{Effect of Single-Stage Aging Time on the Microstructure}

In Figure 11, TEM images of the welded joints aged at $130{ }^{\circ} \mathrm{C}$ for different times are demonstrated. As it can be seen in Figure 11, there is no obvious change in the average precipitate size. Initially, the density of the precipitates increased, and then, as the aging time increased, it decreased. Figure 12 shows the SAED analysis of TEM images, where the precipitates were identified as $\eta^{\prime}$ and $\eta$ phases. The average precipitate size and area fraction of the precipitates at different aging times are shown in Figure 13. As it can be observed, after $12 \mathrm{~h}$, the fine precipitates were in the size range of $4-6 \mathrm{~nm}$, with an average precipitate size of $5 \mathrm{~nm}$ and an area fraction of $12.6 \%$. With the increase of time to $24 \mathrm{~h}$, the average precipitate size was in the range of 4-6 nm, with an average precipitate size of $5 \mathrm{~nm}$, and the area fraction increased to $34.6 \%$. After $28 \mathrm{~h}$, the average precipitate size was still in the range of 4-6 $\mathrm{nm}$ and the area fraction decreased slightly to $32.6 \%$. 

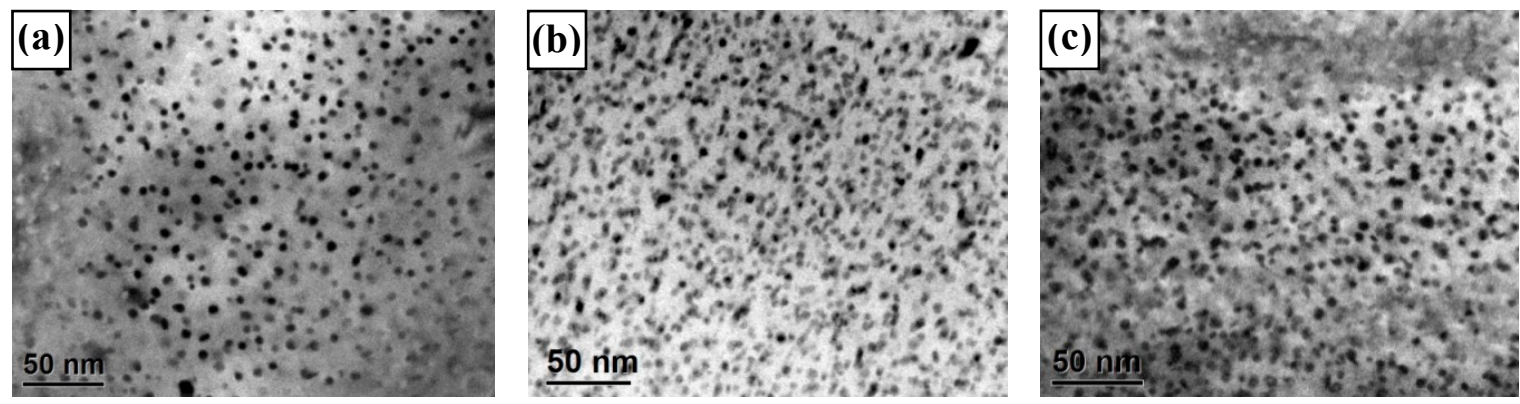

Figure 11. TEM images of the weld center aged at $130{ }^{\circ} \mathrm{C}$ for different times (a) $12 \mathrm{~h}$; (b) $24 \mathrm{~h}$; (c) $28 \mathrm{~h}$.
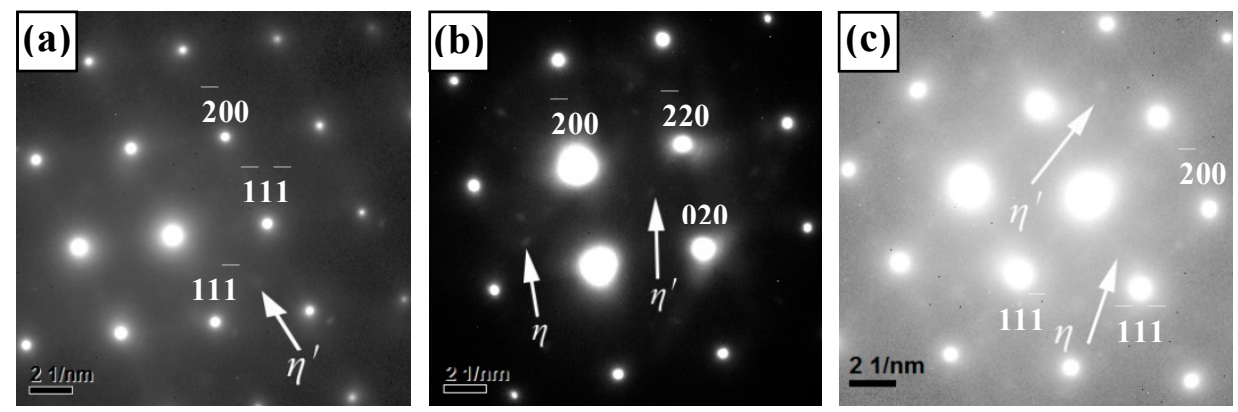

Figure 12. SAED patterns of the weld center aged at $130{ }^{\circ} \mathrm{C}$ for different times (a) $12 \mathrm{~h}<011>$; (b) $24 \mathrm{~h}$ $<001>$; (c) $28 \mathrm{~h}<011>$.

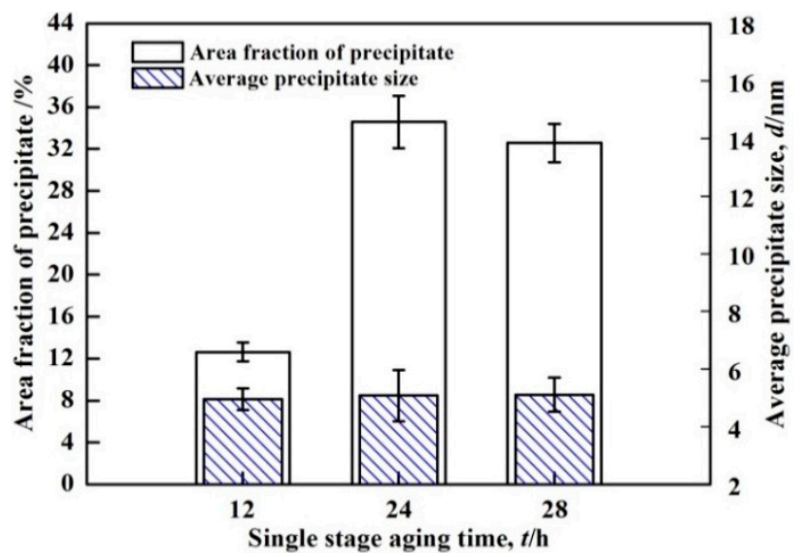

Figure 13. Area fraction of precipitates and average precipitate sizes aged at $130{ }^{\circ} \mathrm{C}$ for different times.

\section{Discussion}

In this study, a 7075 aluminum alloy was welded by PVPPAW using ER5183 (Al-Mg alloy) filler wire, and the effect of single-stage aging on the welded joint was systematically investigated. The tensile strength and the microhardness were enhanced by single-stage aging treatment, as shown in Figure 4 and Figure 5. Single-stage aging was an effective method for improving the mechanical properties of welded joints. The improvement of the mechanical properties of the welded joint was due to the precipitation strengthening $[14,15,35]$. The main alloying elements ( $\mathrm{Zn}, \mathrm{Mg}$, and $\mathrm{Cu}$ elements) in the 7075 aluminum alloy PVPPAW joint were the same as in the 7075 aluminum alloy. Consequently, the precipitation sequence in the welded joint would be the same as in an A1- $\mathrm{Zn}-\mathrm{Mg}-\mathrm{Cu}$ alloy. The most common precipitation process that occurs during aging treatment in $\mathrm{Al}-\mathrm{Zn}-\mathrm{Mg}-\mathrm{Cu}$ alloys is as follows: supersaturated solid solution state-coherent GP zones-semi-coherent $\eta^{\prime}$ phase-incoherent $\eta$ phase [23]. The GP zone and $\eta^{\prime}$ phase play an important role in strengthening the alloy, while the strengthening effect of the $\eta$ phase is weak. During aging, the size, quantity, and distribution of precipitates such as GP zones, and $\eta^{\prime}$ and $\eta$ phases determine the mechanical properties of welded 
joints. The final mechanical properties of welded joints are determined by the size of the particles, the interfacial relationship of particles with the matrix, and the grain boundary characteristics [36].

According to the results, the precipitate phase of the 7075 aluminum alloy PVPPAW joint mainly consists of a few GP zones and $\eta^{\prime}$ phase after an aging time of $12 \mathrm{~h}$, and thus the tensile strength of the welded joint is low. Moreover, the precipitation phases of the welded joints are mainly $\eta^{\prime}$ phase and $\eta$ phase under aging at $140^{\circ} \mathrm{C}$, and thus the tensile strength of the welded joint is slightly higher than after $12 \mathrm{~h}$. Under aging at $130^{\circ} \mathrm{C}$, the tensile strength is the highest due to the fact that the precipitated phases are mainly GP zones and an abundance of $\eta^{\prime}$ phase. According to the dislocation theory, Gleiter and Ashby [37] analyzed the shearing and bypassing mechanisms in detail, and the following equations were obtained:

$$
\begin{aligned}
& \tau_{G}=k_{1} \frac{\gamma_{A}^{3 / 2} f^{1 / 3}}{\sqrt{G} b^{2}} r^{1 / 2}+\tau_{0} \\
& \tau_{A}=k_{2} \frac{G b f^{1 / 2}}{r} \ln \frac{2 r}{r_{0}}+\tau_{0}
\end{aligned}
$$

where $\tau_{G}$ and $\tau_{A}$ are the strengths of the material under the shearing and bypassing mechanisms, respectively; $k_{1}$ and $k_{2}$ are constants; $G$ is the shear modulus; $f$ is the volume fraction of particles; $r$ is the radius of particles; $b$ is the Bernoulli vector; $\tau_{0}$ is the strength of the matrix; $\gamma_{A}$ is the antiphase domain boundary energy; and $r_{0}$ is the radius of the dislocation core. From Equations (1) and (2), it can be deduced that the strengthening effect of the shearing mechanism increases with the increase of the volume fraction and the size of the particles, while the strengthening effect of the bypassing mechanism decreases with the decrease of the volume fraction and the increase of the particle size.

The present work can be reasonably explained by means of shearing and bypassing mechanisms [38-40]. The volume fraction and the average precipitate size are smaller at $120{ }^{\circ} \mathrm{C}$, as shown in Figure 8a. The tensile strength of the welded joint is lower owing to the fact that the dislocation cuts the GP zone and $\eta^{\prime}$ phases by moving dislocations [39]. When the temperature is $140{ }^{\circ} \mathrm{C}$, the volume fraction of the precipitates decreases and the size of some precipitates increases compared to that aged at $130{ }^{\circ} \mathrm{C}$. The hardness and the tensile strength would be decreased due to the coarsening of precipitate dispersion and the decrease of volume fraction [14], which could be explained by $\eta^{\prime}$ or $\eta$ precipitate bypassing mechanisms [40]. Our results are consistent with this theory; the dislocation bypassed $\eta^{\prime}$ phase and $\eta$ phase particles during deformation, the strengthening effect decreases, and the tensile strength of the welded joint at $140{ }^{\circ} \mathrm{C}$ is lower than under an aging temperature of $130^{\circ} \mathrm{C}$, as shown in Figures 4,5 and 8 .

At $130{ }^{\circ} \mathrm{C}$, the precipitated phases are mainly GP zones and $\eta^{\prime}$ phase. The volume fraction of the precipitated phases is much larger than that at $120^{\circ} \mathrm{C}$ and $140{ }^{\circ} \mathrm{C}$. In addition, the precipitate size is similar to that at $120^{\circ} \mathrm{C}$, but smaller than that at $140{ }^{\circ} \mathrm{C}$. The tensile strength of the welded joint is higher according to the precipitation shearing mechanism [38]. The volume fraction of the precipitated phase initially increases, and then, as the aging time increases, it decreases. Therefore, the tensile strength of the welded joint initially increases, and then decreases, after reaching the peak value under the combined action of the shearing and bypassing mechanism, as the increase of both the aging temperature and time.

Aging treatment has a certain effect on electrical conductivity. The precipitated amount of solute atoms in the matrix increased with the aging process. At the beginning of aging, a large amount of solute atoms precipitate within the matrix, leading to a poor solid solution, and this results in the rapid increase of electrical conductivity. The total conductivity increases, since the effect of the poor solid solution is greater than the additional scattering effect of the precipitating electrons. The higher the aging temperature, the more solute atoms will precipitate from the matrix, which results in a higher conductivity. With an increase of the aging time, the $\eta^{\prime}$ and $\eta$ phases are continuously precipitated within the matrix, and the electrical conductivity increases monotonously. It is advantageous to improve the electrical conductivity by increasing the aging temperature and prolonging the aging 
time, due to the fact that the stress corrosion resistance of the welded joint is better when the electrical conductivity is higher. This theory has also been proved by the literature [29].

\section{Conclusions}

The effects of single-stage aging treatment on the mechanical properties of 7075 aluminum alloy PVPPAW joints were systematically investigated. The aging treatment can adequately overcome the softening problem of 7075 aluminum alloy PVPPAW joints.

(1) With the increase of single-stage aging temperature and time, the tensile strength of the welded joint initially increased, and then decreased. Under aging treatment at $130{ }^{\circ} \mathrm{C}$ for $24 \mathrm{~h}$, an ultimate tensile strength of $551 \mathrm{MPa}$ was obtained, which was about $93.5 \%$ of that of base metal, and improved by about $38.5 \%$ compared to the as-welded joint.

(2) The change rules of precipitation under different aging temperatures and times were analyzed. A large number of the $\eta^{\prime}$ phase precipitated during the aging treatment. The area fraction was initially increased with the increase of temperature and time, and then decreased, while the average precipitate size was slightly increased with the increase of the aging temperature, but no obvious change was observed with the increase of the aging time.

(3) The electrical conductivity of the welded joint increased with the increase of the single-stage aging temperature and time, which led to the increase of stress corrosion resistance.

Author Contributions: Conceptualization, G.L. and Y.H.; Methodology, G.L. and F.C.; Formal Analysis, Y.L. and L.S.; Investigation, G.L. and Y.L.; Resources, F.C. and Y.H.; Data Curation, Y.L.; Writing-Original Draft Preparation, G.L.; Writing-Review and Editing, Y.L.; Visualization, G.L. and L.S.; Supervision, F.C.; Project Administration, Y.H.; Funding Acquisition, F.C. and Y.H.

Funding: This study was financially supported by the National Natural Science Foundation of China (No. 51665044); the Grassland Talent Foundation of Inner Mongolia, China (No. CYYC5033); Inner Mongolia University of Technology Foundation (No. ZZ201807) and the Opening Foundation of Key Basic Research of Inner Mongolia.

Conflicts of Interest: The authors declare no conflict of interest.

\section{References}

1. Williams, J.C.; Starke, E.A. Progress in structural materials for aerospace systems. Acta Mater. 2003, 51, 5775-5799. [CrossRef]

2. Heinz, A.; Haszler, A.; Keidel, C.; Moldenhauer, S.; Benedictus, R.; Miller, W.S. Recent development in aluminum alloys for aerospace applications. Mater. Sci. Eng. A 2000, 280, 102-107. [CrossRef]

3. Clark, R.; Coughran, B.; Traina, I.; Hernandez, A.; Scheck, T.; Etuk, C.; Peters, J.; Lee, E.W.; Ogren, J.; Es-Said, O.S. On the correlation of mechanical and physical properties of 7075-T6 Al alloy. Eng. Fail. Anal. 2005, 12, 520-526. [CrossRef]

4. Li, J.F.; Peng, Z.W.; Li, C.X.; Jia, Z.Q.; Chen, W.J.; Zheng, Z.Q. Mechanical properties, corrosion behaviors and microstructures of 7075 aluminum alloy with various aging treatments. Trans. Nonferrous Metals Soc. China 2008, 18, 755-762. [CrossRef]

5. Tajally, M.; Emadoddin, E. Mechanical and anisotropic behaviors of 7075 aluminum alloy sheets. Mater. Des. 2011, 32, 1594-1599. [CrossRef]

6. Lee, W.S.; Sue, W.C.; Lin, C.F.; Wu, C.J. The strain rate and temperature dependence of the dynamic impact properties of 7075 aluminum alloy. J. Mater. Process. Tech. 2000, 100, 116-122. [CrossRef]

7. Chang, C.C.; Chen, C.L.; Wen, J.Y.; Cheng, C.M.; Chou, C.P. Characterization of hot cracking due to welding of high strength aluminum alloys. Mater. Manuf. Process. 2012, 27, 658-663. [CrossRef]

8. Feng, A.H.; Chen, D.L.; Ma, Z.Y. Microstructure and cyclic deformation behaviour of a friction-stir-welded $7075 \mathrm{Al}$ alloy. Metall. Mater. Trans. A 2010, 41, 957-971. [CrossRef]

9. Nunes, A.C.; Bayless, E.O.; Jones, C.S.; Munafo, P.M.; Biddle, A.P.; Wilson, W.A. Variable polarity plasma arc welding on space shuttle external tank. Weld. J. 1984, 63, 27-35.

10. Zheng, B.; Wang, H.J.; Wang, Q.L.; Kovacevic, R. Control for weld penetration in VPPAW of aluminum alloys using the front weld pool image signal. Weld. J. 2000, 12, 363-371. 
11. Han, Y.Q.; Du, M.H.; Chen, S.J.; Yu, Y.J.; Shi, Y. Process control of variable polarity keyhole plasma arc welding for aluminum alloy. Trans. China Weld. Inst. 2010, 31, 93-98.

12. Zhang, L.; Li, X.Y.; Nie, Z.R.; Huang, H.; Sun, J.T. Softening behavior of a new Al-Zn-Mg-Cu alloy due to TIG welding. J. Mater. Eng. Perform. 2016, 25, 1870-1879. [CrossRef]

13. Ma, T.; Ouden, G.D. Softening behavior of Al-Zn-Mg alloys due to welding. Mater. Sci. Eng. A 1999, 266, 198-204. [CrossRef]

14. Mahathaninwong, N.; Plookphol, T.; Wannasin, J.; Wisutmethangoon, S. T6 heat treatment of rheocasting $7075 \mathrm{Al}$ alloy. Mater. Sci. Eng. A 2012, 532, 91-99. [CrossRef]

15. Aoba, T.; Kobayashi, M.; Miura, H. Effects of aging on mechanical properties and microstructure of multidirectionally forged 7075 aluminum alloy. Mater. Sci. Eng. A 2017, 700, 220-225. [CrossRef]

16. Fribourg, G.; Deschamps, A.; Bréchet, Y. Precipitation strengthening in AA7449 aluminum alloy: understanding the relationship between microstructure, yield strength and strain hardening. Mater. Sci. Forum 2006, 519, 991-996. [CrossRef]

17. Park, J.K. Influence of retrogression and re-ageing on the strength and stress corrosion resistance of aluminum alloy 7075-T6. Mater. Sci. Eng. A 1988, 103, 223-231. [CrossRef]

18. Reda, Y.; Abdel-Karim, R.; Elmahallawi, I. Improvements in mechanical and stress corrosion cracking properties in Al-alloy 7075 via retrogression and reaging. Mater. Sci. Eng. A 2008, 485, 468-475. [CrossRef]

19. Starink, M.J.; Wang, S.C. A model for the yield strength of overaged Al-Zn-Mg-Cu alloys. Acta Mater. 2003, 51, 5131-5150. [CrossRef]

20. Song, M.; Chen, K.H. Effects of the enhanced heat treatment on the mechanical properties and stress corrosion behavior of an Al-Zn-Mg alloy. J. Mater. Sci. 2008, 43, 5265-5273. [CrossRef]

21. Isadare, A.D.; Aremo, B.; Adeoye, M.O.; Olawale, O.J.; Shittu, M.D. Effect of heat treatment on some mechanical properties of 7075 Aluminum Alloy. Mater. Res. 2013, 16, 190-194. [CrossRef]

22. Lavernia, E.; Rai, G.; Grant, N.J. Rapid solidification processing of $7 \times \times \times$ aluminum alloys: a review. Mater. Sci. Eng. 1990, 79, 211-221. [CrossRef]

23. Cam, G.I.S.E.G. Effects of temper condition and post weld heat treatment on the microstructure and mechanical properties of friction stir butt-welded AA7075 Al alloy plates. Int. J. Adv. Manuf. Technol. 2014, 70, 201-213.

24. Kumar, P.V.; Reddy, G.M.; Rao, K.S. Microstructure, mechanical and corrosion behavior of high strength AA7075 aluminum alloy friction stir welds-Effect of post weld heat treatment. Defence Technol. 2015, 11, 362-369. [CrossRef]

25. Wang, X.J.; Sun, G.P.; Zhang, J.; Xu, C.; Li, S.W.; Niu, Y. Effects of heat treatment after welding on friction stir welding joints of high-strength aluminum alloy. Chin. J. Nonferrous Met. 2009, 19, 484-489.

26. Chen, C.; Chen, F.R.; Zhang, H.J. One-step aging behavior of 7A52 aluminum alloy laser welded joint. Rare Metal Mater. Eng. 2018, 47, 1589-1595.

27. Yan, K.; Shi, Z.Q.; Wang, X.L. Influence of heat treatment on microstructure and mechanical properties of spray formed $7 \times \times \times$ series aluminum alloy TIG weld joint. Trans. China Weld. Inst. 2012, 33, 33-40.

28. Li, G.W.; Chen, F.R.; Han, Y.Q.; Liang, Y.H. Improving mechanical properties of PVPPA welded joints of 7075 aluminum alloy by PWHT. Materials 2018, 11, 379.

29. Zhang, Y.K.; Xu, X.J.; Luo, Y.; Song, T.; Wang, H.Y.; Wu, G.C.; Zhang, Z.Q. Tensile property and exfoliation corrosion of 7075 aluminum alloy after enhanced-solid-solution and T76 aging treatment. Rare Metal Mater. Eng. 2012, 41, 612-615.

30. Li, X.Z.; Hansen, V.; Gjønnes, J.; Wallenberg, L.R. HREM study and structure modeling of the $\eta^{\prime}$ phase, the hardening precipitates in commercial A1-Zn-Mg alloys. Acta Mater. 1999, 47, 2651-2659. [CrossRef]

31. Gao, M.; Feng, C.R.; Wei, R.P. An analytical electron microscopy study of constituent particles in commercial 7075-T6 and 2024-T3 alloys. Metall. Mater. Trans. A 1998, 29, 1145-1151. [CrossRef]

32. Löffler, H.; Kovács, I.; Lendvai, J. Decomposition processes in Al-Zn-Mg alloys. J. Mater. Sci. 1983, 18, $2215-2240$. [CrossRef]

33. Svoboda, M.; Janovec, J.; Jenko, M.; Vrankovic, A. The characterisation of intermetallic compound particles in an annealed Al-Mg-Cr-Fe alloy. Mater Technol. 2004, 38, 289-294.

34. Viana, F.; Pinto, A.M.P.; Santos, H.M.C.; Lopes, A.B. Retrogression and re-ageing of 7075 aluminum alloy: microstructural characterization. J. Mater. Process Technol. 1999, 92, 54-59. [CrossRef]

35. Zou, X.L.; Yan, H.; Chen, X.H. Evolution of second phases and mechanical properties of $7075 \mathrm{Al}$ alloy processed by solution heat treatment. Trans. Nonferrous Metals Soc. China 2017, 27, 2146-2155. [CrossRef] 
36. Emani, S.V.; Benedyk, J.; Nash, P.; Chen, D. Double aging and thermomechanical heat treatment of AA7075 aluminum alloy extrusions. J. Mater. Sci. 2009, 44, 6384-6391. [CrossRef]

37. Verhecen, J.D.; Lu, G.X.; Hao, Z.W. Translation. The Basis of Physical Metallurgy; Shanghai Scientific \& Technical Publishers: Shanghai, China, 1980.

38. Shercliff, H.R.; Ashby, M.F. A process model for age hardening of aluminum alloys-I. The model. Acta Metall. Mater. 1990, 38, 1789-1802. [CrossRef]

39. Chen, J.Z.; Zhen, L.; Yang, S.J.; Shao, W.Z.; Dai, S.L. Investigation of precipitation behavior and related hardening in AA 7055 aluminum alloy. Mater. Sci. Eng. A 2009, 500, 34-42. [CrossRef]

40. Guyot, P.; Cottignies, L. Precipitation kinetics, mechanical strength and electrical conductivity of $\mathrm{AlZnMgCu}$ alloys. Acta Mater. 1996, 44, 4161-4167. [CrossRef]

(C) 2019 by the authors. Licensee MDPI, Basel, Switzerland. This article is an open access article distributed under the terms and conditions of the Creative Commons Attribution (CC BY) license (http:// creativecommons.org/licenses/by/4.0/). 